\title{
Effects of delays to cooling and wrapping on strawberry quality (cv. Sweet Charlie)
}

\author{
M.C.N. Nunes, ${ }^{\dagger}$ J.K. Brecht, ${ }^{\ddagger}$ S.A. Sargent ${ }^{\ddagger}$ and \\ A.M.M.B. Morais ${ }^{\ddagger *}$
}

\begin{abstract}
'Sweet Charlie' strawberries were wrapped with PVC polymeric film, and forced-air precooled after delays of 0,6 or 8 hours at $30^{\circ} \mathrm{C}$ to study the effect of delaying precooling on physical and chemical quality characteristics of the strawberry. Non-wrapped fruits were used as a control. Evaluations were performed after storage for one week at $1^{\circ} \mathrm{C}$ plus one day at $20^{\circ} \mathrm{C}$. Delaying the precooling resulted in less attractive fruits and loss of quality characteristics. Wrapped strawberries maintained better appearance and quality than nonwrapped berries.
\end{abstract}

Keywords: strawberry, forced air cooling, packaging, colour, firmness, ascorbic acid, sugars, water loss

\section{INTRODUCTION}

The strawberry is one of the most perishable fruits and temperature has the greatest effect on its quality. At high temperatures, respiration greatly increases leading to a depletion of nutrient reserves, and, therefore, fruit senescence is accelerated. For each $10^{\circ} \mathrm{C}$ rise in temperature respiration activity is increased by a factor of two or three. For instance at $0^{\circ} \mathrm{C}$ the strawberry has a respiration rate of about $18 \mathrm{mg} \mathrm{CO} / \mathrm{kg} / \mathrm{h}$ and at $27^{\circ} \mathrm{C}$ the respiration rate is greatly increased, reaching a ratio of $211 \mathrm{mg} \mathrm{CO} / \mathrm{kg} / \mathrm{h}$ (Hardenburg et al., 1986). Prompt removal of field heat and adequate packaging can slow down undesirable quality changes and increase the shelf-life of strawberries (Arifin and Chau, 1987; Boyette et al., 1989; Talbot and Chau, 1991). Storage at about $1{ }^{\circ} \mathrm{C}$ seems to be the optimum temperature to maintain strawberry appearance and marketing quality (Maynard et al., 1988; Boyette et al., 1989; Collins and Perkins-Veazie, 1993). However, immediate precool-

${ }^{\dagger}$ Escola Superior de Biotecnologia, Rua Dr. António Bernardino de Almeida, 4200 Porto, Portugal. ${ }^{*}$ Horticultural Sciences Department, University of Florida, Gainesville, Florida, USA. ${ }^{*}$ To whom correspondence should be addressed. ing of strawberries with forced air and subsequent storage at $1^{\circ} \mathrm{C}$ is not often attained as strawberries are usually left on the field under the sun and exposed to high temperatures. Mitchell et al. (1964) noticed a decrease in the amount of marketable fruits as a result of holding the strawberries at high temperature for $8 \mathrm{~h}$ in the field before cooling.

Packaging of fruits with polymeric films is often used to prevent moisture loss, to protect against mechanical damage, and to achieve a better appearance (Hening and Gilbert, 1975). However, packaging strawberries with plastic films immediately after harvest is not a common technique and water loss may be considerable during storage. The water loss may lead to shrivelling and a dull appearance of the epidermis having a negative effect on the appearance of the fruit. The maximum permissible water loss for strawberries before marketability is impaired has been reported to be approximately $6 \%$ (Robinson et al., 1975).

The objective of this work is to evaluate the effects of short delays to cooling and packaging on the quality of strawberries. Differing lengths of delay before cooling were used to study the effects on strawberry quality after harvest. The effect if a PVC polymeric film wrapping was also tested. Quality measurements were 
performed after storage for a week at $1^{\circ} \mathrm{C}$ plus a simulated retail display period of a day at $20^{\circ} \mathrm{C}$ in order to determine if differences would be apparent at the consumer level for strawberries handled identically except for the timing of precooling.

\section{MATERIAL AND METHODS}

\section{Plant material}

'Sweet Charlie' strawberries were obtained from a commercial operation near Floral City, Florida. 'Sweet Charlie' is the most recent release from the University of Florida strawberry breeding programme (Chandler et al., 1992). The strawberries were grown in double rows on raised beds covered with a black plastic mulch, with drip irrigation and fertilization practices according to standard recommendations for strawberry production in Florida (Maynard $e t$ al., 1988). The fungicides iprodione (Rovral) and captan were applied weekly throughout the season for decay control.

\section{Treatment and storage conditions}

Commercially harvested fruits packed in fibreboard flats, containings 12 plastic mesh pint baskets of strawberries were removed from the field with minimal delay after harvest and transported from Floral City to the laboratory in Gainesville within approximately two hours. Berries from two flats, a total of 240 fruits, were selected for uniformity of colour development (threequarters to full ripe) and freedom of defects, weighed in samples of 10 berries, and redistributed in 24 plastic pint baskets containing 10 berries each. Half of the baskets were wrapped with a polyvinyl chlorine (PVC) plastic film (FilmCo. W4475) with $0.0181 \mathrm{~mm}$ thickness and permeability $\mathrm{m}^{3}$ at STP $\mathrm{m} / \mathrm{m}^{2} / \mathrm{s} / \mathrm{atm} \times 10^{14}$ to carbon dioxide and to oxygen, 618.9 and 59.8 respectively, at $3^{\circ} \mathrm{C}$ (Talasila, 1992). The package was not completely sealed as the objective was not to create a modified atmosphere package, but to avoid water loss. The other baskets were used as a control (nonwrapped).

All the baskets were then placed in a controlled temperature room at $35^{\circ} \mathrm{C}$ and $70-80 \% \mathrm{RH}$. Fruit pulp temperature reached $30^{\circ} \mathrm{C}$ within an hour, at which time the strawberries were either immediately transferred to a $1^{\circ} \mathrm{C}$ room for forced air cooling or maintained at $30^{\circ} \mathrm{C}$ for $6-8 \mathrm{~h}$ and then transferred to $1^{\circ} \mathrm{C}$ for cooling. This procedure was followed in order to simulate field temperature and minimize water loss differences between treatments. The berries were removed from the forced air unit when the fruit pulp temperature reached $4^{\circ} \mathrm{C}$ (within $1 \mathrm{~h}$ under these conditions). The strawberries were then stored at $1^{\circ} \mathrm{C}$ and $90-95 \% \mathrm{RH}$ for one week. After a week, the strawberries were transferred to $20^{\circ} \mathrm{C}$ and $80-85 \% \mathrm{RH}$ for one day. Physical and chemical properties were measured using four samples of 10 berries per treatment.

\section{Weight loss}

Fruits were individually weighed before and after storage, and weight loss was calculated. Concentrations of chemical constituents were expressed in terms of dry weight. The dry weight was determined by drying a weighed aliquot of homogenized fruit tissue at $70^{\circ} \mathrm{C}$ for six days and then reweighing.

\section{Colour assessment}

Fruit surface colour intensity was measured with a hand-held tristimulus reflectance colorimeter (Model CR-200b, Minolta Corp., Ramsey, New Jersey, USA). Colour was recorded using the CIE $-L^{*} a^{*} b^{*}$ uniform colour space (CIE-Lab), where $L^{*}$ indicates lightness, $a^{*}$ indicates chromaticity on a green $(-)$ to red $(+)$ axis, and $b^{*}$ chromaticity on a blue $(-)$ to yellow $(+)$ axis (Francis, 1980).

\section{Firmness measurements}

Fruit firmness ( $3 \mathrm{~mm}$ deformation) was measured with an Inston Universal Testing Instrument (Model 1132, Instron Corp., Canton, USA). A $50 \mathrm{~kg}$ load cell was used for the firmness determination of fruits. Crosshead speed was $10 \mathrm{~cm} / \mathrm{min}$. A $16 \mathrm{~mm}$ diameter convex tip Magness-Taylor type probe was used and data was plotted using a strip recorder at $5 \mathrm{~kg}$ full scale. This test measured berry firmness based on the resistance of the berry flesh to deformation by the penetrometer probe. Results in kgf were converted to Newton (N).

\section{Soluble solids}

Replicate samples of 10 berries were homogenized in a laboratory blender at high speed for two minutes. The homogenate was centrifuged at $800 \times g$ for $30 \mathrm{~min}$, filtered through cheesecloth, and the soluble solids contents of the resulting juice was determined with an Abbé refractometer. Soluble solids content was expressed in terms of dry weight.

\section{pH}

The $\mathrm{pH}$ of the puree was determined using a $\mathrm{pH}$ meter (Model 140, Corning Medical and Scientific Instruments, Medfield, Mass., USA) which was standardized to $\mathrm{pH} 4$ and $\mathrm{pH} 7$.

\section{Titratable acidity}

Fruits were blended and the puree centrifuged at 2000 $\mathrm{rpm}$ for 30 minutes. Then filtered, aliquots $(6.00 \mathrm{~g})$ of juice were diluted with $100 \mathrm{ml}$ distilled water. The titratable acidity was determined by titration with $0.1 \mathrm{~N}$ $\mathrm{NaOH}$ to an end point of $\mathrm{pH}=8.1$ with an automatic titrimeter (Fisher Scientific Co., Pittsburgh, PA, USA). The results were calculated as percent of citric acid $[(\mathrm{ml} \mathrm{NaOH} \times 0.1 \mathrm{~N} \times 0.064 / 6.00 \mathrm{~g}$ of juice $) \times$ $100]$, and expressed in terms of dry weight. 


\section{Ascorbic acid}

For total ascorbic acid analysis, $5 \mathrm{~g}$ of blended fruit were combined with $100 \mathrm{ml}$ of a mixture of $6 \%$ metaphosphoric and $2 \mathrm{~N}$ acetic acids. The fruit-acid mixture was centrifuged for 20 minutes at $5000 \mathrm{rpm}$. The analysis was performed by the dinitrophenylhydrazine method of Terada et al. (1978). The concentration of total ascorbic acid was calculated per $100 \mathrm{~g}$ of dry weight tissue from absorbance measured at $540 \mathrm{~nm}$ using a standard curve.

\section{Sugars}

Fructose, glucose and sucrose were determined by the analysis of their trimethylsilyl derivatives, prepared using Pierce STOX-oxime reagent (Pierce, Rockford, Illinois, USA) and N-trimethylsilylimidazole. A Gas Chromatograph (Model 540, Tractor Instruments, Austin, Texas, USA) equipped with a flame ionization detector (FID) and connected to a $244 \times 0.3 \mathrm{~cm}$ column packed with $3 \%$ OV 17, 80-100 mesh Chromosorb WP, with a flow rate for helium (carrier gas) of 40 $\mathrm{ml} / \mathrm{min}$ was used for separation of the silylated sugars. The temperature of the column oven was programmed for $140^{\circ} \mathrm{C}$ for $3 \mathrm{~min}$ and subsequently for $8^{\circ} \mathrm{C} / \mathrm{min}$ to $250^{\circ} \mathrm{C}$, and injector temperatures were set at $285^{\circ} \mathrm{C}$ and $300^{\circ} \mathrm{C}$, respectively. Results were expressed in terms of dry weight.

\section{Statistical analysis}

The Statistical Analysis System computer package (SAS Institute, Inc., 1982) was used for analysis of data in these experiments. Significant differences between wrapped and non-wrapped fruits, and between 0,6 and $8 \mathrm{~h}$ were detected using the Duncan's multiple range test.

\section{RESULTS AND DISCUSSION}

The berries lost more weight when cooling was delayed longest. Since the cooling and storage conditions were identical for 0,6 and $8 \mathrm{~h}$ delay treatments, the differences in weight loss must be due primarily to water loss during the delay before cooling. Weight loss was highest for non-wrapped strawberries, precooled after an $8 \mathrm{~h}$ delay at $30^{\circ} \mathrm{C}$ (Figure 1). Wrapped samples presented a weight loss significantly higher $(p<0.05)$ than non-wrapped samples. After storage, weight loss by strawberries precooled immediately after harvest ranged from $1.9 \%$ in wrapped strawberries to $9.9 \%$ in non-wrapped strawberries, while delaying precooling increased weight loss from $3.1 \%$ to $16.7 \%$ in wrapped and non-wrapped strawberries, respectively. The water loss had a negative effect on the strawberry fruit appearance, leading to shrivelling and a dull appearance of the epidermis.

Aharoni and Barkai-Golan (1987) studied the effect of different wraps on the weight loss of strawberries

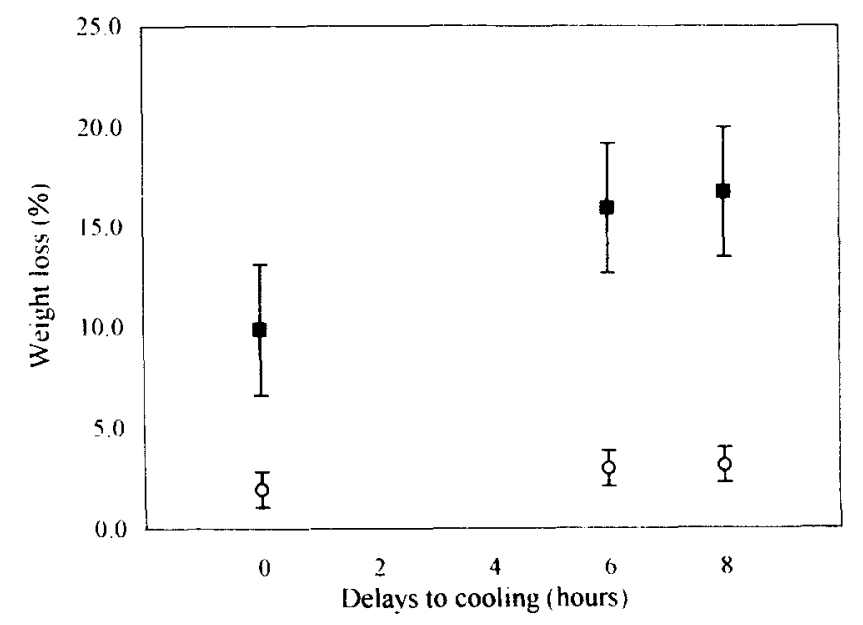

Figure 1 Effects of delays to cooling and wrapping on the weight loss of strawberry (cv. Sweet Charlie). O, wrapped; $\mathbf{0}$, non-wrapped.

and also noticed that packaging with PVC wraps resulted in a marked reduction in water loss. Collins and Parkins-Veazie (1993) in another study of strawberries noticed less weight loss in fruits packed in polystyrene boxes, during storage at $1^{\circ} \mathrm{C}$ and $5^{\circ} \mathrm{C}$. Miller et al. (1983) studied the effects of different consumer units in the quality of strawberries under simulated air-freight shipping conditions and observed that berries packed in a rigid plastic basket with a solid plastic cover lost significantly less weight than those stored in mesh plastic baskets with or without covers.

Delaying the precooling resulted in berries with significantly lower $L^{*}$ and $a^{*}$ than promptly precooled fruits (Figure 2). However, non-wrapped berries were darker (lower $L^{*}$ value) and less red (lower $a^{*}$ value) than wrapped fruits. These colour changes resulted in less attractive fruit and may be a consequence of the great moisture loss and over-ripeness of the fruit from the delayed treatment.

When the firmness was initially measured as the bioyield point, the results suggested that the unwrapped berries from the delayed treatment were actually firmer than berries cooled immediately after harvest (data not shown), but this result appeared to be due to toughening of the epidermis as a consequence of a great water loss rather than retention of flesh firmness. When the firmness data were expressed as the force required to compress a berry by $3 \mathrm{~mm}$, flesh firmness was shown to be lower in the berries from the delayed treatment. Firmness of wrapped and non-wrapped strawberries cooled immediately after harvest was greater than those cooled after a $6 \mathrm{~h}$ or a $8 \mathrm{~h}$ delay (Figure 3). In addition, wrapped strawberries were firmer than the non-wrapped.

The dry weight of the strawberries in the experiments averaged about $10 \%$ of the initial fresh weight (data not shown). This level of dry weight is in accordance with other published figures for strawberries (McCance and Widdowson, 1978; US Dept of Agriculture, 1991). The higher levels of water loss in the strawberries from the 6 $h$ and $8 \mathrm{~h}$ delays to cooling treatments tended to mask 

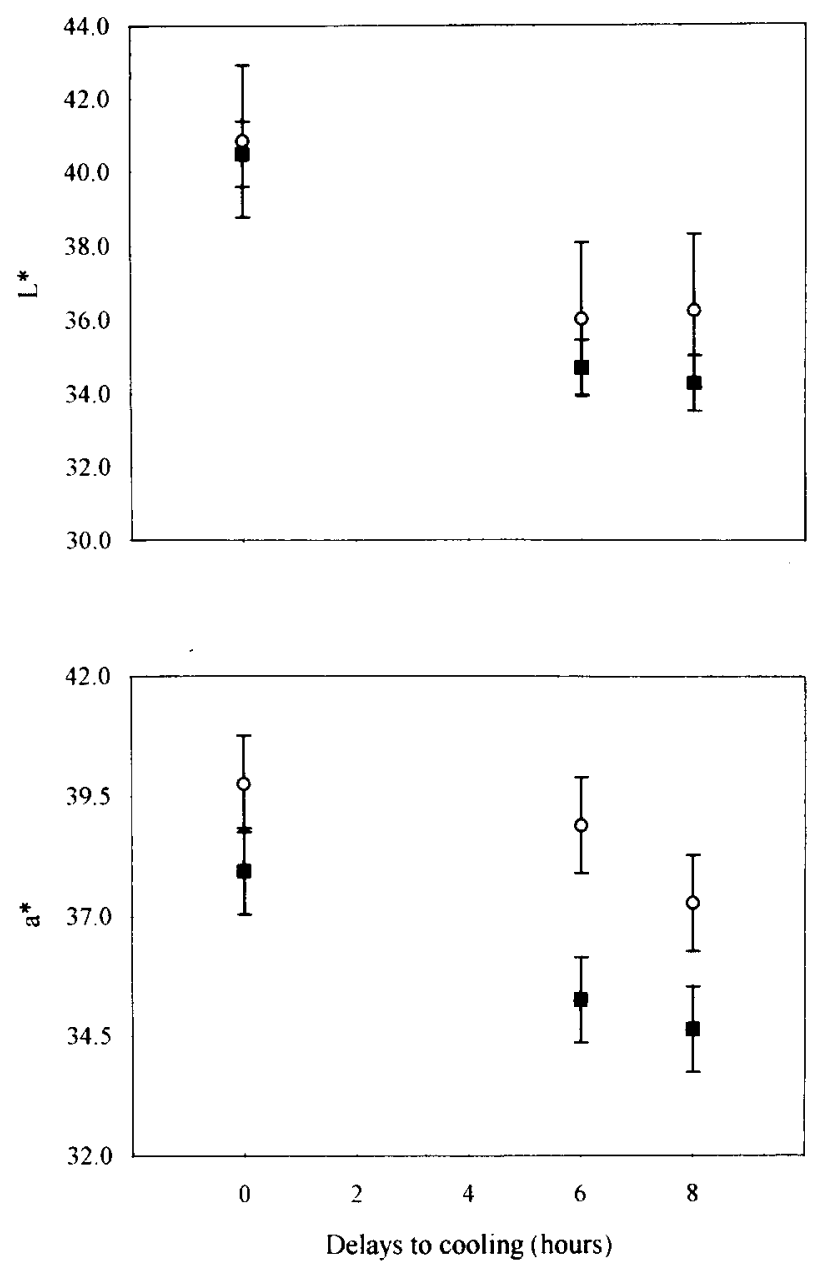

Figure 2 Effects of delays to cooling and wrapping of the colour of strawberry (cv. Sweet Charlie). o, wrapped; a, non-wrapped.

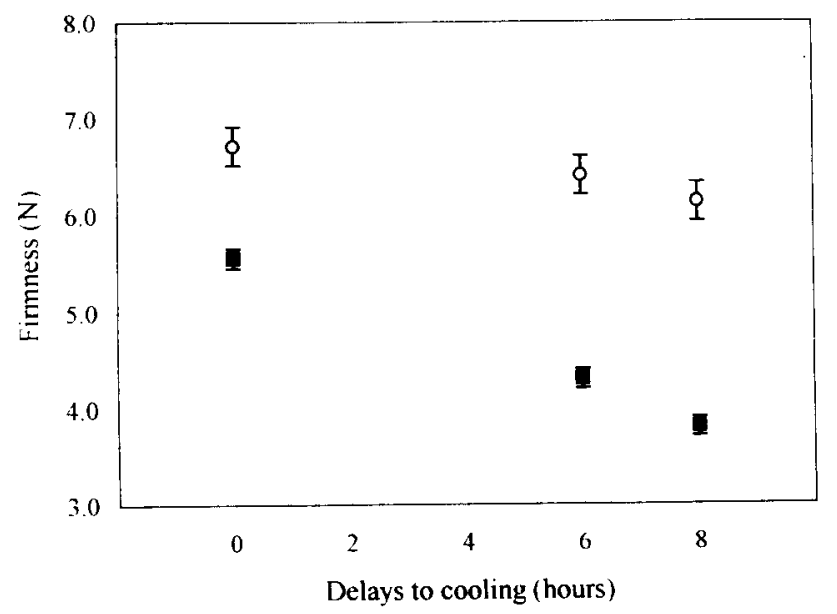

Figure 3 Effects of delays to cooling and wrapping on firmness of

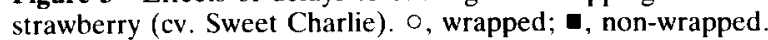

real losses of some constituents on the fresh weight basis. Therefore, we have expressed the compositional data on a dry weight basis in order to illustrate the actual losses that occurred in certain constituents irrespective of the concentrating effect imposed by water loss.

Berry $\mathrm{pH}$ was little affected by the delay treatments and by wrapping with PVC. Acidity levels decreased

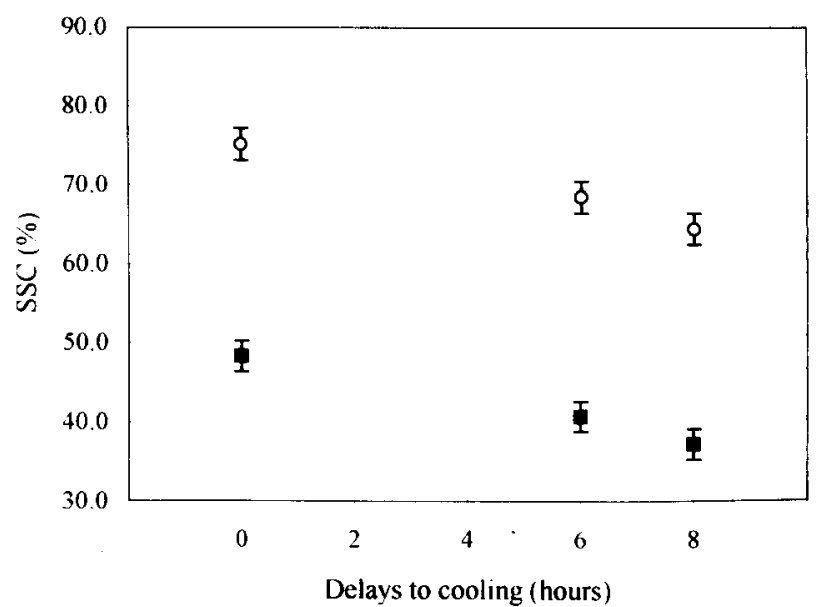

Figure 4 Effects of delays to cooling and wrapping on the soluble solids content of strawberry (cv. Sweet Charlie). O, wrapped; $\mathbf{m}$, non-wrapped.

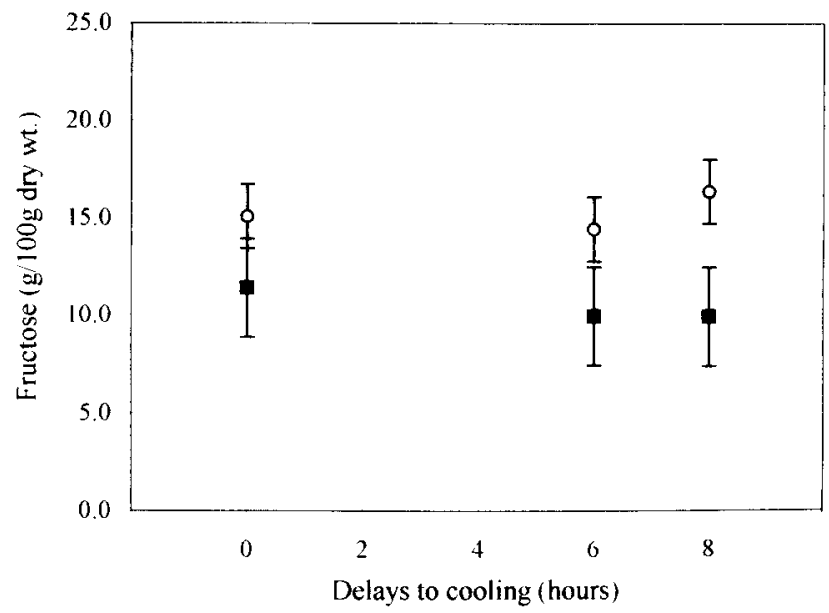

Figure 5 Effects of delays to cooling and wrapping on the fructose content of strawberry (cv. Sweet Charlie). o, wrapped; a, nonwrapped.

when precooling was delayed and was more pronounced in non-wrapped strawberries (data not shown). Acidity levels have been reported to decrease in overripe strawberries (Woodward, 1972). Soluble solid content (SSC) was lower with the delay treatments than with no delay to cooling (Figure 4). Non-wrapped strawberries showed a significant decrease in SSC when compared with wrapped berries.

Sugar levels were substantially lower in non-wrapped berries after the delay treatments (Figures 5, 6 and 7). Although not significant, an increase in fructose and glucose for the $8 \mathrm{~h}$ delay treatment was noticed for both wrapped and non-wrapped strawberries. A similar trend was noticed for fructose in wrapped fruits. This increase might possibly be due to a polysaccharide breakdown of the cell walls (Fenemma, 1985) which might be accelerated by the exposure of the fruits to a high temperature $\left(30^{\circ} \mathrm{C}\right)$ for a longer period of time before cooling. This effect could overcome the effect of respiration. However, sucrose level decreases significantly when precooling is delayed and this decrease was more severe in non-wrapped berries (Figure 8). 


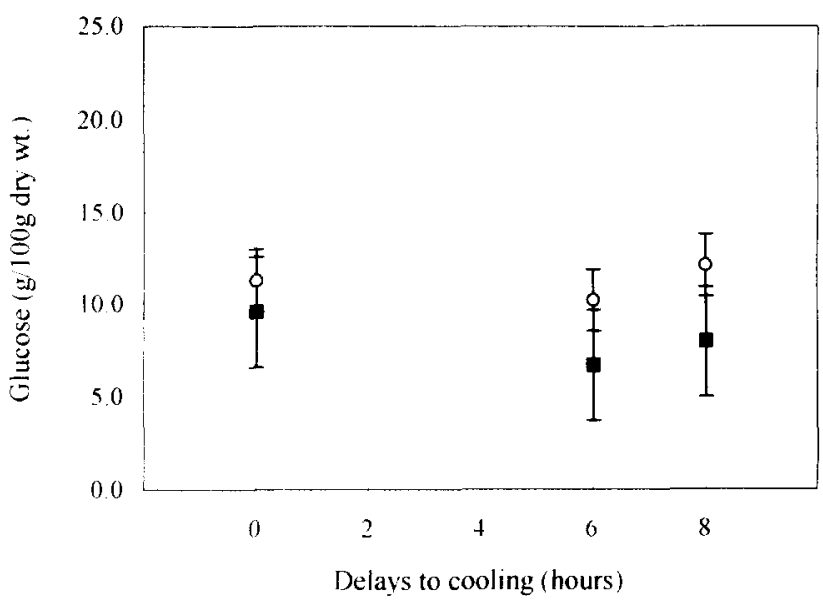

Figure 6 Effects of delays to cooling and wrapping on the glucose content of strawberry (cv. Sweet Charlie). O, wrapped; 0 , nonwrapped.

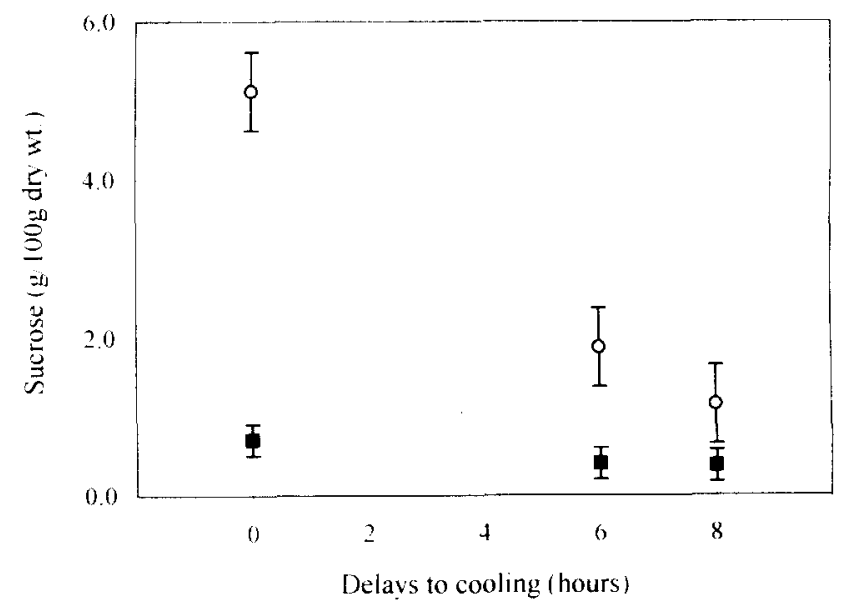

Figure 7 Effects of delays to cooling and wrapping on the sucrose content of strawherry (cv. Sweet Charlie). O, wrapped; $\boldsymbol{a}$, nonwrapped.

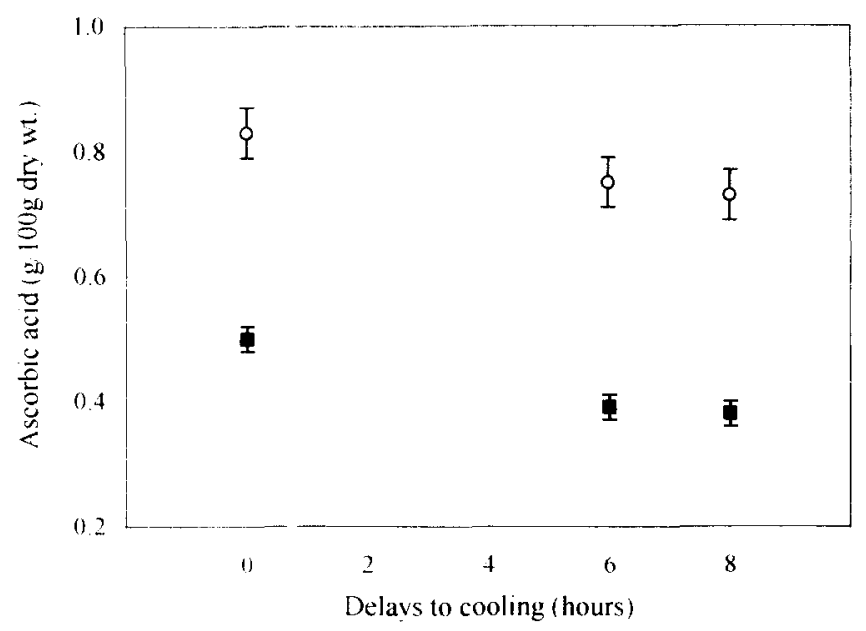

Figure 8 Effects of delays to cooling and wrapping on ascorbic content of strawberry (cv. Sweet Charlie). $O$, wrapped; $\mathbf{a}$, nonwrapped.

Ascorbic acid content was higher in berries submitted to no delay treatment and in wrapped strawberries (Figure 8). Water loss seems to have a negative effect on ascorbic acid content. In a study with broccoli, spinach and lettuce Zepplin and Elvehjem (1944) noticed that refrigeration under high humidity gave a favourable retention of ascorbic acid. Nelson et al. (1977) also suggested that high moisture content in asparagus might protect the ascorbic acid. Barth et al. (1990) studied the effects of misting on ascorbic acid retention in broccoli during cabinet display at $18^{\circ} \mathrm{C}$ and noticed that the misted broccoli samples retained more ascorbic acid than the non-misted samples. They also observed that broccoli incurred significant ascorbic acid losses with increased storage time. Barth et al. (1993) in a subsequent study with broccoli using modified atmosphere packaging noticed a moisture retention in packaged broccoli due to a higher humidity inside the package, and also an increase in ascorbic acid loss in non-packaged broccoli. They attributed this loss to autoxidation of the ascorbic acid. In another study using fresh vegetables Ezell and Wilcox (1959) also noticed that those that lose moisture readily and wilt appreciably tend to be more affected by humidity and lose ascorbic acid more rapidly than those resistant to wilting.

\section{CONCLUSIONS}

The physical and chemical quality characteristics of strawberries were negatively affected by delaying the precooling. When the cooling was delayed for $6 \mathrm{~h}$ or $8 \mathrm{~h}$ at $30^{\circ} \mathrm{C}$, the strawberries were significantly softer, more shrivelled, had less attractive colour and the acidity, SSC, sugars and ascorbic acid levels were lower than in fruit that were wrapped and promptly cooled. These differences were all apparent after seven days storage at $1^{\circ} \mathrm{C}$ plus one day at $20^{\circ} \mathrm{C}$, conditions simulating normal transport and marketing times and optimum temperature for strawberries. Thus, a rather modest and probably not unusual (in commercial handling) delay between harvest and cooling of strawberries was shown to have significant negative effects on appearance, nutritive value, and presumably acceptability, that would be expected to persist at the consumer level. Therefore, a rapid precooling of fresh strawberries and subsequent storage at $1^{\circ} \mathrm{C}$, and the use of a PVC polymeric film to wrap the fruits immediately after harvest seem to be critical for maintaining the quality of strawberry.

\section{ACKNOWLEDGEMENTS}

This research work was supported by a grant from JNICT (Junta Nacional de Investigaçāo Científica e Tecnológica), Portugal.

\section{REFERENCES}

Aharoni, Y. and Barkai-Golan, R. (1987) Pre-harvest fungicide sprays and polyvinyl wraps control Botrytis rot and prolong the 
post-harvest storage life of strawberries. J. Horticultural Science 62 (2), 177-181

Arifin, B.B. and Chau, K.V. (1987) Forced-air cooling of strawberries. ASAE paper No. $87-6004$

Barth, M.M., Kerbel, E.L., Perry, A.K. and Schmidt, S.J. (1993) Modified atmosphere packaging affects ascorbic acid, enzyme activity and market quality of broccoli. J. Food Sci. 58 (1), $140-143$

Barth, M.M., Perkey, A.K., Schmidt, S.J. and KJein, B.P. (1990) Misting effects on ascorbic acid retention in broccoli during cabinet display. J. Food Sci. 55 (4), 1187-1188, 1191.

Boyette, M.D., Wilson, L.G. and Estes, E.A. (1989) Postharvest cooling and handling of strawberries. AG. Raleigh, North Carolina Agricultural Extension Service.

Chandler, C.K., Sumler Jr, J.C. and Albergts, E.A. (1992) Performance of 'Oso Grande', FL 85-4925, and FL 87-236 strawberry during the 1991-1992 season. Proc. Fla. State Hort. Soc. 105, 348-349

Collins, J.K. and Perkins-Veazie, P. (1993) Postharvest changes in strawberry fruits stored under simulated retail display conditions. J. Food Qual. 16, 133-143

Ezell, D.B. and Wilcox, M.S. (1959) Loss of vitamin C in fresh vegetables as related to wilting and temperature. J. Agric. Food Chem. 7 (7), 507-509

Fenemma, O.R. (editor) (1985) Food Chemistry. Second Edition, Marcel Dekker, New York, pp 857-911

Francis, F.J. (1980) Colour quality evaluation of horticultural crops. Hort Science 15, 58-59

Hardenburg, R.E., Watada, A.E. and Wang, C.Y. (1986) The Commercial Storage of Fruits, Vegetables, and Florist and Nursery Stocks. USDA, Agriculture Handbook 66, 130 pp

Hening, Y.S. and Gilbert, S.G. (1975) Computer analysis of the variables affecting respiration and quality of produce packaged in polymeric films. J. Food Sci. 40, 1033-1035

Maynard, D.N., Hochmuth, G.J. and Sherman, M. (1988) Strawberry Production Guide for Florida. Florida Cooperative Extension Service-IFAS, University of Florida, Circular 142C
MeCance, R.A. and Widdowson, E.M. (1978) The Comparison of Foods. Elsevier/North Holland Biomedical Press, London, $417 \mathrm{pp}$

Miller, W.R., Davis, P.L., Dow, A. and Bongers, A.J. (1983) Quality of strawberries packed in different consumer units and stored under simulated air-freight shipping conditions. HortScience 18 (3), 310-312

Mitchell, F.G., Maxie, E.C. and Greathead, C.E. (1964) Handling strawberries for fresh market. University of California. Division of Agricultural Sciences. Circular 527

Nelson, J.W., Drake, S.R., Carter, G.H. and Early, R.E. (1977) Fresh asparagus quality affected by field cut and holding conditions. College of Agriculture Research Center, Washington State University, Pullman, Bull. No. 846

Robinson, J.E., Browne, K.M. and Burton, W.G. (1975) Storage characteristics of some vegetables and soft fruits. Ann. Appl. Biol. 81, 399-408

SAS Institute, Inc. (1982) SAS User's Guide: Statistics. Cary, North Carolina, $584 \mathrm{pp}$

Talasila, P.C. (1992) Modelling of heat and mass transfer in a modified atmosphere package. A dissertation presented to the graduate school of the University of Florida for the degree of Doctor of Philosophy.

Talbot, M. and Chau, K.V. (1991) Precooling strawberries. Florida Cooperative Extension Service. Institute of Food and Agricultural Sciences. University of Florida. Circular 942

Terada, M., Watanabe, Y., Kunitoma, M. and Hayashi, E. (1978) Differential rapid analysis of ascorbic acid and ascorbic acid 2-sulfate by dinitrophenylhydrazine method. Anal. Biochem. 84 , 604-608

United States Department of Agriculture (1991) Nutritive value of foods. Service/Home and Garden Bulletin 72, 26 pp

Woodward, J.R. (1972) Physical and chemical changes in developing strawberry fruits. J. Sci. Food Agric. 23, 465-473

Zepplin, M. and Elvehjem, C.A. (1944) Effect of refrigeration on retention of ascorbic acid in vegetables. Food Research 9, 100-111 